\title{
PREZENTACJE
}

Andrzej Felchner

(Piotrków Trybunalski)

\section{Zakład Historii i Teorii Wychowania \\ w Filii Akademii Świętokrzyskiej w Piotrkowie Trybunalskim oraz Piotrkowskie Koło Towarzystwa Historii Edukacji}

W roku 2007 doszło do powstania w Piotrkowie Trybunalskim Koła Towarzystwa Historii Edukacji. Nastąpiło to w kilkanaście lat po utworzeniu w naszej Uczelni placówki zajmującej się programowo tą dziedziną nauki.

Obecna piotrkowska Filia kieleckiej Akademii Swiętokrzyskiej (na mocy decyzji Sejmu RP z 23 stycznia 2008 r. przekształcanej aktualnie w Uniwersytet Jana Kochanowskiego w Kielcach) powstała w roku 1981 jako niewielki Zamiejscowy Wydział Pedagogiczny ówczesnej Wyższej Szkoły Pedagogicznej w Kielcach. Początkowo prowadzono jedynie 3-letnie studia zawodowe, ale już w roku akademickim 1984/1985 uruchomiono 5-letnie studia magisterskie na kierunku pedagogika, początkowo dla studentów niestacjonarnych (zaocznych), a po roku również dla stacjonarnych (dziennych). Pod koniec lat 80 . zaczęto wyodrębniać poszczególne Zakłady. $Z$ historyków zajmujących się dziejami oświaty i wychowania pracowali już wtedy doc. dr hab. Ryszard Wacław Wołoszyński oraz dr Jerzy Kukulski. Pierwszy z wymienionych został w roku 1991 mianowany profesorem nadzwyczajnym Wyższej Szkoły Pedagogicznej i objął w roku akademickim 1991/1992 stanowisko kierownika tworzonej wówczas Katedry Historii Wychowania (od 1992 r. Zakładu). Prof. R. W. Wołoszyński pełnił tę funkcję do 1 października 1998 r., do chwili przejścia do piotrkowskiego Instytutu Historii. Jego następczynią została, pracująca w naszej Uczelni od początku lat 90., dr hab. Teresa Wróblewska, także profesor nadzwyczajny WSP - Akademii Świętokrzyskiej, historyk, która zajmowała to stanowisko do roku akademickiego 2004/2005, pełniąc również inne ważne funkcje - prodziekana i dyrektora Instytutu. W omawianym czasie zaszły też istotne zmiany - WSP przekształciła się w Akademię Świętokrzyską, a w roku 2000 z Wydziału Zamiejscowego utworzono Filię o dwóch wydziałach, a sama nasza placówka została przekształcona w Zakład Historii i Teorii Wychowania Instytutu Nauk Pedagogicznych Wydziału Nauk Społecznych. Po odejściu z Filii prof. T. Wróblewskiej przez rok akademicki 2004/2005 kierownictwo placówki piastował prof. nadzw. AŚ dr hab. Jerzy Kukulski, poprzednio Prorektor Akademii Świetokrzyskiej do spraw Filii, zajmujący się między innymi historią gospodarczą oraz dziejami regionu, w tym miejscowej oświaty. 
Po Jego odejściu na emeryturę funkcję kierownika pełniła (przez rok) adiunkt dr Joanna Majchrzyk-Mikuła, a ranga placówki (zgodnie z przepisami) musiała zostać obniżona do Pracowni. Od roku akademickiego 2006/2007 ponownie działa Zakład Historii i Teorii Wychowania, a jego kierownikiem został prof. nadzw. AŚ dr hab. Andrzej Felchner, poprzednio (od r. a. 1997/1998) pracujący w Instytucie Historii Filii, pierwszy jego dyrektor i były prodziekan Wydziału Filologiczno-Historycznego, wywodzący się ze środowiska łódzkiego. W ciągu całego omawianego okresu z Zakładem związani byli również, w różny sposób w niektórych latach, między innymi profesorowie i doktorzy: Tadeusz Dąbkowski, Włodzimierz Goriszowski, Jan Góral, Tadeusz Jałmużna, Ryszard Kotewicz, Kazimierz Rędziński, Czesław Wiśniewski, czy Jerzy Wojciechowski.

Niewątpliwie dużo Zakład zawdzięcza dwom pierwszym kierownikom, którzy postawili go na wysokim poziomie naukowym i dydaktycznym. Profesor R. W. Wołoszyński, wywodzący się ze środowiska warszawskiego, związany z Instytutem Historii Nauki, Oświaty i Techniki PAN, Uniwersytetem Warszawskim oraz Centrum Doskonalenia Nauczycieli swoje badania koncentruje głównie wokół problematyki epoki oświecenia, już po odejściu z naszego Zakładu otrzymał tytuł naukowy profesora. Druga z wymienionych - profesor T. Wróblewska, poprzednio pracująca między innymi w Uniwersytecie Mikołaja Kopernika w Toruniu oraz w Wyższej Szkole Pedagogicznej w Słupsku, zajmuje się dziejami oświaty w ubiegłym XX stuleciu, utrzymuje bliskie kontakty z wieloma placówkami zagranicznymi, głównie w Niemczech, stąd Jej zainteresowania problematyką polsko-niemiecką, a także wiele publikacji również w języku niemieckim. W tym też czasie działało studenckie koło korczakowskie, ponadto Zakład zorganizował sesję naukową poświęconą J. Piagetowi.

Obecnie, w roku akademickim 2007/2008, skład Zakładu przedstawia się następująco: kierownik - prof. AŚ dr hab. A. Felchner, adiunkci, doktorzy (wszyscy są pedagogami): Ewa Krochmalska-Gawrosińska, J. Majchrzyk-Mikuła i Janusz Tomiło. Ostatni $\mathrm{z}$ wymienionych zajmuje się głownie teorią wychowania, a także andragogiką (również w ujęciu historycznym), $\mathrm{z}$ tego obszaru przygotowuje rozprawę habilitacyjną pod roboczym tytułem: „Wychowanie dorosłych - między tradycją a nowoczesnością”. Jest on również założycielem i redaktorem naczelnym „Artes Liberales" - naukowego periodyku wydawanego w Pułtusku. Doktor E. Krochmalska-Gawrosińska obok prowadzenia uczelnianego Studium Pedagogicznego publikuje z zakresu historii polskiej oświaty na przełomie XIX/XX w. (np. o Henryku Rowidzie), a obecnie koncentruje się na badaniach regionalnych, zamierzając z tej problematyki przygotować swoją habilitację. Doktor J. Majchrzyk-Mikuła również zajmowała się podobnym okresem, między innymi opublikowała monografię poświęconą działalności kobiet $w$ oświacie na ziemiach polskich na przełomie XIX/XX w., a aktualnie koncentruje swoje badania na problematyce polskiej medycyny szkolnej w XX w. i zamierza je ukoronować rozprawą habilitacyjną. Można jeszcze dodać, iż obie Panie Adiunkt są już wychowankami piotrkowskiej Uczelni. Kierownik Zakładu zajmował się między innymi historią Polski XX w., w tym problematyką wojskowego szkolnictwa medycznego $\mathrm{i}$ badaniami regionalnymi, a aktualnie, łącząc swe dawne i obecne zainteresowania, poświęcił się badaniom problemów zdrowotności ze szczególnym uwzględnieniem dzieci i młodzieży oraz medycynie szkolnej w Polsce. 
Chcąc bardziej rozwinąć działalność naukową, a także nawiązać szersze kontakty ze środowiskiem historyków oświaty i wychowania postanowiliśmy przeprowadzić wstępne rozmowy w tej sprawie z Prezesem Towarzystwa Historii Edukacji prof. dr. hab. Karolem Poznańskim. Miały one miejsce w stolicy na początku roku 2007 i uczestniczyli w nich z naszej strony: prof. AŚ A. Felchner i dr J. Majchrzyk-Mikuła. Uzyskane tam informacje, a także konsultacje telefoniczne $\mathrm{z}$ innymi członkami władz THE - prof. dr hab. Wiesławem Jamrożkiem oraz dr Marzeną Pękowską - pozwoliły zwołać pierwsze zebranie organizacyjne. Odbyło się ono 19 kwietnia 2007 r. w Instytucie Nauk Pedagogicznych Filii w Piotrkowie Trybunalskim, przy ul. J. Słowackiego 114/118, w pomieszczeniach wspomnianego Zakładu. Poza wymienionymi wyżej dwoma osobami założycielami Koła i pierwszymi jego członkami są pozostali adiunkci Zakładu: dr E. Krochmalska-Gawrosińska oraz dr J. Tomiło, a także mgr Małgorzata Olszewska z Instytutu Historii Filii i mgr Katarzyna Szymczyk, pracownik administracyjny Instytutu Nauk Pedagogicznych. Wszyscy $\mathrm{z}$ wymienionych prowadzą badania naukowe $\mathrm{z}$ historii oświaty $\mathrm{i}$ wychowania, przygotowując między innymi prace na kolejne stopnie naukowe (pełny ówczesny dorobek naukowy w/w znajduje się w aktach zarówno Zarządu, jak i Piotrkowskiego Koła THE).

Na powyższym pierwszym spotkaniu jednomyślnie postanowiono, że kierunkami działalności powstającego Koła będzie:

1) propagowanie historii oraz tradycji polskiej oświaty i szkolnictwa w miejscowym środowisku zarówno w samym mieście, jak i poza nim;

2) wspieranie i udzielanie pomocy w działalności naukowej członków Koła, szczególnie przy przygotowywaniu przez nich prac na kolejne stopnie naukowe, przez urządzanie zebrań i dyskusji w miejscowym środowisku akademickim;

3) współpraca zarówno $w$ ramach Towarzystwa $z$ innymi środowiskami historyków oświaty w całym kraju, (szczególnie z kieleckim), jak i różnymi Towarzystwami Naukowymi działającymi w Piotrkowie Trybunalskim, na przykład z Kołem Polskiego Towarzystwa Historycznego;

4) nawiązanie i rozwinięcie współpracy z miejscowym środowiskiem nauczycielskim;

5) powołanie do życia i aktywnej działalności studenckiego koła historyków oświaty.

Uczestnicy posiedzenia upoważnili kierownika Zakładu do ostatecznego opracowania i przesłania wszystkich wymaganych dokumentów do Zarządu Głównego THE, co też uczyniono jeszcze w kwietniu $2007 \mathrm{r}$.

W odpowiedzi Zarząd Główny Towarzystwa Historii Edukacji na swym posiedzeniu w dniu 9 września 2007 r. podjął uchwałę, „na mocy której powołane zostało Piotrkowskie Koło Towarzystwa Historii Edukacji" (cytat z oficjalnego pisma Zarządu). Na tej podstawie w dniu 7 grudnia 2007 r., również, tak jak poprzednio, w siedzibie Zakładu Historii i Teorii Wychowania INP Filii odbyło się pierwsze zebranie wyborcze Koła. Do tego czasu akces do niego zgłosiło kilka następnych osób. Na posiedzeniu władze Wydziału Nauk Społecznych i Instytutu Nauk Pedagogicznych Filii reprezentował Prodziekan dr Paweł Plaskura. W wyniku przeprowadzonych tajnych wyborów ukonstytuował się pierwszy zarząd Koła w składzie: przewodniczący prof. AŚ dr hab. A. Felchner, sekretarz mgr K. Szymczyk, skarbnik dr J. Tomiło. Do Komisji Rewizyjnej Koła wybrano: 
prof. dr hab. T. Wróblewską i dr J. Majchrzyk-Mikułę. Przyjęto również plan pracy zgodny z uchwalonymi w kwietniu, powyżej omówionymi, głównymi kierunkami działalności Koła. Zobowiązano także dr J. Majchrzyk-Mikułę i mgr M. Olszewską do utworzenia w Filii studenckiego koła historyków oświaty, a dr E. Krochmalską-Gawrosińską i mgr Annę Uniszewską do nawiązania kontaktów ze środowiskiem nauczycielskim.

W dniu 31 grudnia 2007 r. Piotrkowskie Koło Towarzystwa Historii Edukacji liczyło 11 członków, w tym: trzech samodzielnych pracowników naukowych (poza wymienionymi akces zgłosił także prof. zw. dr hab. Edward Alfred Mierzwa, urzędujący Dyrektor Instytutu Historii Filii) oraz czterech doktorów z Instytutów: Pedagogiki i Historii Filii. Większość to pracownicy naszej Uczelni, tylko dwie osoby pracują poza nią.

W roku 2008 rozpoczęto normalną statutową działalność Koła.

\section{Andrzej Felchner}

\section{The Department of History and Theory of Education in the Branch in Piotrk6w Trybunalski of the Jan Kochanowski University of Humanities and Sciences. Piotrków Trybunalski Circle of the History of Education Society}

In Piotrków Trybunalski, in the academic year of 1984-1985, a 5-year Master's Degree Studies in Pedagogics were launched. The school, over the 25 -year span, has been significantly enlarged. At present, the Institute of Pedagogic Studies forms a part of the faculty of Social Sciences of the Jan Kochanowski University of Humanities and Sciences in Kielce. From the start, the history of learning, education and pedagogical thought have been taught. The current didactic and scientific activities in this subject are conducted by the Department of History and Theory of Education. The institution was successively directed by professors: Ryszard Wołoszyński, Teresa Wróblewska, Jerzy Kukulski and today by Andrzej Felchner. Additionally, in 2007, Piotrków Trybunalski Circle of the History of Education Society was established. It groups scholars from the Branch as well as the employees of other educational institutions from Piotrków Trybunalski. 